\title{
Dynamic of Morphological and Physiological Parameters and Variation of Soil Characteristics during Miscanthus $\times$ giganteus Cultivation in the Diesel-Contaminated Land
}

\author{
Valentina Pidlisnyuk ${ }^{1}\left(\mathbb{D}\right.$, Andriy Herts $^{2}\left(\mathbb{D}\right.$, Volodymyr Khomenchuk ${ }^{2}$, Aigerim Mamirova ${ }^{1,3, *(D)}$, \\ Oleksandr Kononchuk ${ }^{2}$ iD and Sergey Ust'ak ${ }^{4}$ (D)
}

1 Department of Environmental Chemistry and Technology, Jan Evangelista Purkyně University, 40096 Usti nad Labem, Czech Republic; valentyna.pidlisniuk@ujep.cz

2 Faculty of Chemistry and Biology, Ternopil Volodymyr Hnatiuk National Pedagogical University, 46027 Ternopil, Ukraine; herts@chem-bio.com.ua (A.H.); homenchuk@chem-bio.com.ua (V.K.); kononchuk@chem-bio.com.ua (O.K.)

3 Faculty of Biology and Biotechnology, Al-Farabi Kazakh National University, Almaty 050400, Kazakhstan

4 Czech Crop Research Institute, 43001 Chomutov, Czech Republic; ustak@eto.vurv.cz

* Correspondence: a.mamirova.95@gmail.com; Tel.: +420-730-807-327

Citation: Pidlisnyuk, V.; Herts, A.; Khomenchuk, V.; Mamirova, A.; Kononchuk, O.; Ust'ak, S. Dynamic of Morphological and Physiological Parameters and Variation of Soil Characteristics during Miscanthus $\times$ giganteus Cultivation in the Diesel-Contaminated Land. Agronomy 2021, 11, 798 https://doi.org/10.3390/ agronomy 11040798

Academic Editor: Tomasz Głąb

Received: 23 March 2021

Accepted: 16 April 2021

Published: 18 April 2021

Publisher's Note: MDPI stays neutral with regard to jurisdictional claims in published maps and institutional affiliations.

Copyright: (c) 2021 by the authors. Licensee MDPI, Basel, Switzerland. This article is an open access article distributed under the terms and conditions of the Creative Commons Attribution (CC BY) license (https:// creativecommons.org/licenses/by/ $4.0 /)$.

\begin{abstract}
Miscanthus $\times$ giganteus (M. $\times$ giganteus) is a perspective plant produced on marginal and contaminated lands with biomass used for energy or bioproducts. In the current study, $M . \times$ giganteus development was tested in the diesel-contaminated soils (ranged from $250 \mathrm{mg} \mathrm{kg}^{-1}$ to $5000 \mathrm{mg} \mathrm{kg}^{-1}$ ) and the growth dynamic, leaves quantity, plants total area, number of harvested stems and leaves, SPAD and NPQt parameters were evaluated. Results showed a remarkable $M . \times$ giganteus growth in a selected interval of diesel-contaminated soil with sufficient harvested biomass. The amendment of soil by biochar 1 (produced from wastewater sludge) and biochar 2 (produced from a mixture of wood waste and biohumus) improved the crop's morphological and physiological parameters. Biochar 1 stimulated the increase of the stems' biomass, while biochar 2 increased the leaves biomass. The plants growing in the uncontaminated soil decreased the content of $\mathrm{NO}_{3}, \mathrm{pH}(\mathrm{KCl}), \mathrm{P}_{2} \mathrm{O}_{5}$ and increased the content of $\mathrm{NH}_{4}$. Photosynthesis parameters showed that incorporating biochar 1 and biochar 2 to the diesel-contaminated soil prolonged the plants' vegetation, which was more potent for biochar 1. M. $\times$ giganteus utilization united with biochar amendment can be recommended to remediate diesel-contaminated land in concentration range $250-5000 \mathrm{mg} \mathrm{kg}^{-1}$.
\end{abstract}

Keywords: Miscanthus $\times$ giganteus; diesel-contaminated soils; biochar; morphological and physiological parameters

\section{Introduction}

The contamination of soil by hydrocarbons is a severe environmental problem caused mainly by anthropogenic activities, particularly by processing and transportation of fossil fuels or military activities [1]. Hydrocarbon's release deteriorated the land, surface and underground waters [2], which sometimes excluded the contaminated localities from the land bank [3]. Such deteriorated places possess a tremendous hazardous risk to human health and living organisms with potential carcinogenic and mutagenic effects [4,5]. Compared with traditional physical-chemical techniques, bioremediation combined with phytoremediation can offer a sustainable and less expensive alternative to contaminated land restoration even if the time required to reach the target endpoints is often a severe drawback [6]. A plant-assisted remediation technology can be implemented in situ when treating large surface areas of soils contaminated by organics [7]. However, considerable effort is needed to transition technology from the laboratory to the field conditions. In this regard, proper plant selection, the choice of agricultural practices and elimination of the plant's stress are essential components $[8,9]$. 
Miscanthus $\times$ giganteus $(M . \times$ giganteus $)$ is a promising second-generation energy crop $[10,11]$ that showed the ability to grow in marginal and contaminated lands [12-15]. It is a rhizomatous, lignocellulose-rich perennial grass grown worldwide as a source of energy or bio-based products $[16,17]$. This plant shows rapid growth and high yields in soils of various anthropogenic origins and is among recommended biofuel crops for commercial production in countries with limited energy resources [18].

A growing number of studies have described the crop's successful application for phytoremediation of the trace elements (TEs) contaminated soil [19] and soil health improvement during vegetation [20]. However, few publications introduced the plant's successful application to remediate organic's contaminated lands [12], including the petroleum hydrocarbons contaminated soils $[6,21,22]$. Nevertheless, such lands are among the most prevalent polluted areas in the environment $[23,24]$.

During the $M . \times$ giganteus growing process, the soil's parameters changed [12]. Incorporating an amendment to the soil generally improves the plant's production during vegetation and increases the harvested biomass [25-28]. It was reported that adding sludge increased the produced $M . \times$ giganteus biomass during crop cultivation in the post-mining TEs contaminated soil [25-27], and the effect was more substantial with years of cultivation. Adding activated carbon to the soil contaminated by pesticides decreased the uptake of contaminants to the aboveground crop's biomass and made it available for further energy processing [28]. M. $\times$ giganteus demonstrated sufficient development during two vegetation seasons in the TEs contaminated former military soil [29] and three vegetation seasons in the TEs-contaminated post-mining land [19].

Minimal data are available on applying $M . \times$ giganteus to the hydrocarbons contaminated soils $[6,22]$, counting data about plant growth supported by carbon contented amendment-biochar, i.e., porous, the polyaromatic product of an incomplete thermochemical conversion of organic biomass or wastes. This amendment may generally increase crop yields [30]. However, depending on the biochars' properties, plant productivity's impact remains unpredictable mainly due to complex interactions between soil and the environment [31,32]. Remediation of hydrocarbon contaminated soil is still a growing technology that often uses co-bioremediation of plants and microbes [6,7,12].

The simultaneous effect of soil amendment to $M . \times$ giganteus morphological state, growth parameters and soil changes while the plant was cultivated in the diesel-contaminated land was not much under experimental investigation. To overcome this gap, the current research was designed, which had a goal to examine the production of $M . \times$ giganteus in the differently artificially diesel-contaminated soils, to assess the role of two different biochars when the plant was developed in contaminated soils, to research the change of soil parameters during vegetation, and to evaluate the non-photochemical quenching (NPQt) and relative chlorophyll (SPAD) values as a response to plant's stress.

In the current study, the following hypotheses were under research:

(a) Impact of amending soil by biochars to the soil parameters, specifically: $\mathrm{pH}, \mathrm{NO}_{3}$, $\mathrm{NH}_{4}, \mathrm{P}_{2} \mathrm{O}_{5}$, and $\mathrm{K}$ during $M . \times$ giganteus vegetation versus changes of parameters in soil without crops;

(b) Impact of varied diesel concentrations in the soil and its biochar amending to $M . \times$ giganteus development verifying by plant's morphological and physiological parameters;

(c) Ensuring $M . \times$ giganteus adaptive potential while the crop was cultivated in the diesel-contaminated soils, including with biochars via determination of NPQt and SPAD values.

\section{Materials and Methods}

\subsection{Design of the Pot Experiment}

One vegetation season experiment was established in the greenhouse condition using artificially diesel-contaminated soil. The initial soil was taken at the agricultural research field of Volodymyr Hnatiuk National Pedagogical University in Ternopil, Ukraine; the site's GPS coordinates are 49.5418397 N, 25.568175 E. Following World Reference Base for Soil 
Resources classification [33], soil belongs to chernozem (phaeozems). The agrochemical parameters of the soil are presented in Table 1. Following standards [34], the initial soil had a neutral reaction of salt solution, low content of organic matter, low content of mineral nitrogen, high content of phosphorous and slightly high content of potassium.

Table 1. Soil abundance used in the pot experiment.

\begin{tabular}{ccc}
\hline Agrochemical Parameters & Unit & Mean \pm SD \\
\hline $\mathrm{pH}(\mathrm{KCl})$ & & $6.46 \pm 0.03$ \\
Organic matter & $\%$ & $1.13 \pm 0.04$ \\
$\mathrm{NO}_{3}$ & $\mathrm{mg} \mathrm{kg}^{-1}$ & $126 \pm 9$ \\
$\mathrm{NH}_{4}$ & $\mathrm{mg} \mathrm{kg}^{-1}$ & $1.7 \pm 0.2$ \\
$\mathrm{P}_{2} \mathrm{O}_{5}$ & $\mathrm{mg} \mathrm{kg}^{-1}$ & $176 \pm 12$ \\
Exchangeable K & $\mathrm{mg} \mathrm{kg}^{-1}$ & $116.9 \pm 13.2$ \\
\hline
\end{tabular}

The content of TEs in the initial soil was determined using the X-ray fluorescence analysis, and the layout was described in detail in Pidlisnyuk et al. [19]. The results are presented in Table 2. The content of TEs in the initial soil was typical for such sort of soil and did not violate the standards of EC and Ukraine.

Table 2. TEs concentrations in the soil used in the pot experiment; depth of soil sampling: 0-30 cm.

\begin{tabular}{|c|c|c|c|}
\hline \multirow{2}{*}{ TEs } & \multicolumn{2}{|c|}{ MPC, mg kg ${ }^{-1}$} & \multirow{2}{*}{$\begin{array}{l}\text { TEs Concentration in the Soil, } \\
\qquad \mathrm{mg} \mathrm{kg}^{-1}\end{array}$} \\
\hline & EC [35] & Ukraine [34] & \\
\hline $\mathrm{Mn}$ & NA & 1500 & $628.3 \pm 44.4$ \\
\hline $\mathrm{Fe}$ & \multicolumn{2}{|c|}{ NA } & $22,073 \pm 129.6$ \\
\hline $\mathrm{Cu}$ & 100 & 55 & $17.0 \pm 7.5$ \\
\hline $\mathrm{Zn}$ & 200 & 300 & $49.4 \pm 5.7$ \\
\hline $\mathrm{Pb}$ & 60 & 30 & $25.1 \pm 3.5$ \\
\hline
\end{tabular}

The soil sampling was carried out using the standard approach DSTU 4287:2004 [34] from one $5 \times 5 \mathrm{~m}$ testing square. Five samples were taken at the depth $0-0.3 \mathrm{~m}$ using quartering and mixed. That mixed soil was used in the pot experiment. Before the experiment, the soil was dried at air-dried conditions until the constant weight. Dried soil was passed through a sieve with a pore diameter of $2 \mathrm{~mm}$ as requested by DSTU ISO 11464:2007 [36] to remove plant materials and stones, followed by thorough mixing. The soil was stored in hermetic glass containers until use.

The greenhouse experiment was carried out in the pots. After the bottom of the pots was filled with a draining material weighing $1.0 \mathrm{~kg}$, drainage material was covered with gauze and river sand weighing $1.0 \mathrm{~kg}$ and again covered with gauze; thereafter, each pot was filled in with the soil weighing $8.0 \mathrm{~kg}$. To prevent drying of the soil and the diesel release, each pot was covered with a $1 \mathrm{~kg}$ layer of sand. The individual pot with the research soil was $15 \mathrm{~L}$ in volume and weighed $10 \mathrm{~kg}$. The pots were watered, while necessary during vegetation season using the pot water.

The plant studied was M. $\times$ giganteus J.M. Greef and Deuter ex Hodkinson and Renvoize (Angiospermae: Poaceae) [18]. Rhizomes were three-year-old taken from the $M . \times$ giganteus plantation in Zagreb, Croatia; the plantation was established using rhizomes of varieties "Osinnii zoretsvit" cultivated by the Institute of Energy Crops and Sugar Beets, National Academy of Agrarian Science, Ukraine [37].

Two rhizomes of $M . \times$ giganteus were planted in each pot; planting rhizomes had an average size of $20 \mathrm{~cm}$. All pot experiments were established on the same day.

Each of the various experiments was carried out in three replicates. In parallel, one experiment was established with soil without planted rhizomes.

There were three variations of the experiment with soil amendments:

(a) Experiment without amendments (marked as Ctr); 
(b) Experiment with biochar 1 (marked as B1);

(c) Experiment with biochar 2 (marked as B2).

\subsection{Soil Artificial Contamination and Amending}

The collected and prepared soil was artificially contaminated by diesel DSTU 7688:2015 [38], produced from oil per GOST 9965-76 [39] with the mass part of the polycyclic aromatic hydrocarbons equals to $11 \%$. The soil treatment was done in separate batches; each was equal to $30 \mathrm{~kg}$. The mixture was accomplished in the cement router. In the beginning, the soil was mixed with the targeted amount of selected biochar for $30 \mathrm{~min}$, then the calculated amount of diesel was added, and this soil was remixed for another $30 \mathrm{~min}$.

The following concentration of soil contamination by diesel was selected: $0 ; 250 \mathrm{mg} \mathrm{kg}^{-1}$; $1000 \mathrm{mg} \mathrm{kg}^{-1} ; 3000 \mathrm{mg} \mathrm{kg}^{-1} ; 5000 \mathrm{mg} \mathrm{kg}^{-1}$ based on the published literature on the concentration of diesel products in the aged sites [6,21] and diapason of diesel concentrations in the artificially contaminated soil when a crop (oats) demonstrated satisfactory development [40]. A range of diesel concentrations reported for locations where the accidental release occurred during transportation was also considered [3].

Two sorts of soil amendments were used, both organic origins: B1 and B2; amendments were added to the soil in amount 5\% related to the soil weight. That proportion between biochar and treated soil was reported as optimal in phytoremediation processes [41]. B1 was produced by firm Almeco (Czech Republic) from municipal wastewater treatment plant sludge from Brno, Czech Republic. The biochar is referred to the Czech Ministry of Agriculture requests (2000) [42].

B2 was produced by firm F.O.P. Osypenko (Ukraine) as an experimental amendment DSTU EN ISO/EC 17065 [43] and consisted of the mixture of wood biochar-25\%, biohumus $-50 \%$, and sand $-25 \%$. The characteristics of B1 and B2 are presented in Table 3.

Table 3. Elemental analysis of the research amendments (B1 and B2).

\begin{tabular}{ccc}
\hline TEs & B1, $\mathbf{~ g ~ k g ~}^{-\mathbf{1}}$ & B2, $\mathbf{~ g ~} \mathbf{~ k g}^{-\mathbf{1}}$ \\
\hline $\mathrm{Mg}$ & $13,139.6 \pm 1622.4$ & $14,224.3 \pm 2122.1$ \\
$\mathrm{Al}$ & $38,762.9 \pm 767.3$ & $22,223.8 \pm 977.8$ \\
$\mathrm{Si}$ & $141,728.1 \pm 726.8$ & $272,941.6 \pm 1692.0$ \\
$\mathrm{P}$ & $106,458.1 \pm 919.8$ & $46,767.8 \pm 1002.0$ \\
$\mathrm{~S}$ & $15,711.4 \pm 116.1$ & $7510.8 \pm 133.4$ \\
$\mathrm{~K}$ & $10,677.8 \pm 1552.9$ & $60,664.0 \pm 5726.2$ \\
$\mathrm{Ca}$ & $94,085.4 \pm 1143.1$ & $71,290.6 \pm 3621.5$ \\
$\mathrm{Ti}$ & $4811.5 \pm 359.5$ & $4906.0 \pm 927.5$ \\
$\mathrm{Cr}$ & $453.0 \pm 94.5$ & - \\
$\mathrm{Mn}$ & $896.5 \pm 72.4$ & $821.4 \pm 208.3$ \\
$\mathrm{Fe}$ & $123,923.4 \pm 452.1$ & $35,621.2 \pm 411.8$ \\
$\mathrm{Ni}$ & $137.4 \pm 28.1$ & $78.9 \pm 48.9$ \\
$\mathrm{Cu}$ & $627.2 \pm 24.2$ & $152.1 \pm 36.0$ \\
$\mathrm{Zn}$ & $6847.5 \pm 54.9$ & $727.2 \pm 36.4$ \\
$\mathrm{Sr}$ & $485.0 \pm 6.3$ & $554.2 \pm 12.9$ \\
$\mathrm{Zr}$ & $260.6 \pm 5.7$ & $662.3 \pm 14.8$ \\
$\mathrm{Sn}$ & $57.4 \pm 19.6$ & - \\
$\mathrm{Pb}$ & $100.0 \pm 8.4$ & $81.9 \pm 15.4$ \\
\hline
\end{tabular}

There were five artificially contaminated by diesel soils, marked as:

$\mathrm{A}=0 \mathrm{mg} \mathrm{kg}^{-1} ; \mathrm{B}=250 \mathrm{mg} \mathrm{kg}^{-1} ; \mathrm{C}=1000 \mathrm{mg} \mathrm{kg}^{-1} ; \mathrm{D}=3000 \mathrm{mg} \mathrm{kg}^{-1} ; \mathrm{E}=5000 \mathrm{mg} \mathrm{kg}^{-1}$.

Altogether there were 45 pots with two rhizomes of $M . \times$ giganteus planted in each pot; additionally, 15 pots were established with soil without plants. The total number of monitored experimental pots was 60 units, in which $90 \mathrm{M}$. $\times$ giganteus plants were under research. 


\subsection{Analysis of Soil Parameters}

Different soil parameters were monitored during $M . \times$ giganteus growth, which was determined using the standard methods. Total organic matter was determined using the method of Tyurin DSTU 4289:2004 [44]; the content of nitrate's nitrogen was determined following DSTU 4725:2007 [45], the content of ammonium's nitrogen was determined following DSTU 4725:2007 [45]; mobile forms of phosphorus and potassium were determined using Chirikov DSTU 4115:2002 [46,47], the $\mathrm{pH}$ of the soil (salt extracted) was measured following DSTU ISO 10390:2001 [48].

\subsection{Measuring of Plant's Morphological and Physiological Parameters}

Two sorts of parameters were under monitoring:

(a) Changes of plants' bioparameters: height, the number of stems; the number of leaves per one stem; leaves width and length, from which the leaves surface area (LSA) was calculated using the following equation:

$$
\text { LSA }=\text { Leaf length } \times \text { Leaf width } \times 0.67
$$

(b) Changes in plant state during vegetation by measuring chlorophyll fluorescence $[49,50]$. The measurement was made on intact, fully expanded leaves using the MultispeQ v1.0 device [51] linked to the PhotosynQ platform (http:/ /www.photosynq.com/ technology, accessed on 17 February 2021).

The measurements of morphological and physiological parameters were provided for all plants monitored in the pots' experiments. The plant height was determined for the highest and longest leaf, i.e., the stem's height and the leaf's length (Table S1). The measuring was done separately for each designed experiment, including six parallel plants (two plants per pot and three replications). To determine the leaf surface area's assimilation, the sum area of all leaves of six parallel plants in one series was determined. Using these measurements, the morphological parameters (the plant's height and leaf surface area) were statistically calculated.

Each time measuring the physiological parameters, the second fully developed leaf from the plant's top was investigated. There were three repetitions of the same variant of the experiment and two plants in each pot.

The relative chlorophyll (SPAD) content and the non-photochemical quenching (NPQt) were estimated followed the approach described at [51-54].

The pot experiment started on 12 April 2019 and finished on 26 November 2019, when the harvest of $M . \times$ giganteus was done. The experiment's duration was 228 days, and from those measurements of bioparameters were provided from the beginning of vegetation to the appearance of the first yellow leaves. At harvest, the plant's aboveground biomass was cut and weighed (separately leaves and stems) after drying to the constant weight. The drying of biomass was first provided about $6-8 \mathrm{~h}$ in the oven at temperature $100-105^{\circ} \mathrm{C}$, then dried biomass was weighted and again put to the oven; the procedure continued to the constant weight of biomass when the differences between the last two weightings were less than $0.0001 \mathrm{~g}$.

\subsection{Statistical Analysis}

The statistical data processing was conducted using the RStudio software (version 1.3.959, R Studio PBC, 2020). The multivariate analysis of variance (MANOVA) was carried out to detect a statistically significant difference between changes in soil parameters depending on the presence of amendments and $M . \times$ giganteus plants and the level of diesel contamination. MANOVA was also used to estimate $M . \times$ giganteus physiological parameters depending on three factors: soil treatment, diesel contamination levels, and time (changes during one vegetation season) (Tables S2 and S3). When MANOVA proved a significant difference, Tukey's HSD test was performed to compare. Based on Tukey's HSD 
test, treatments were categorized (by letters in descending gradation), and boxplots/graphs were created.

\section{Results and Discussion}

\subsection{Impact of M. $\times$ giganteus Growing to the Parameters of Uncontaminated Soil}

During growth, M. $\times$ giganteus is characterized by high nutrient uptake efficiency because of the extensive root system $[55,56]$. Biochar is considered an amendment that improves soil conditions and stimulates plant development, bioparameters [41], and dry harvested biomass [57]. Generally, adding biochar to the soil results in an increase in soil $\mathrm{pH}$, the total carbon and soil nutrients content [58].

At the first stage, the impact of $M . \times$ giganteus growing to the control uncontaminated soil parameters was evaluated when B1 and B2 amended the soil. The changing of soil parameters, i.e., $\mathrm{pH}, \mathrm{NO}_{3}, \mathrm{NH}_{4}, \mathrm{P}_{2} \mathrm{O}_{5}$, and $\mathrm{K}$ during the vegetation period when M. $\times$ giganteus grew in the pots (labelled as M) and in pots without crops (labelled as W), is presented in Figures 1 and $2 a-d$ (for each parameter separately).

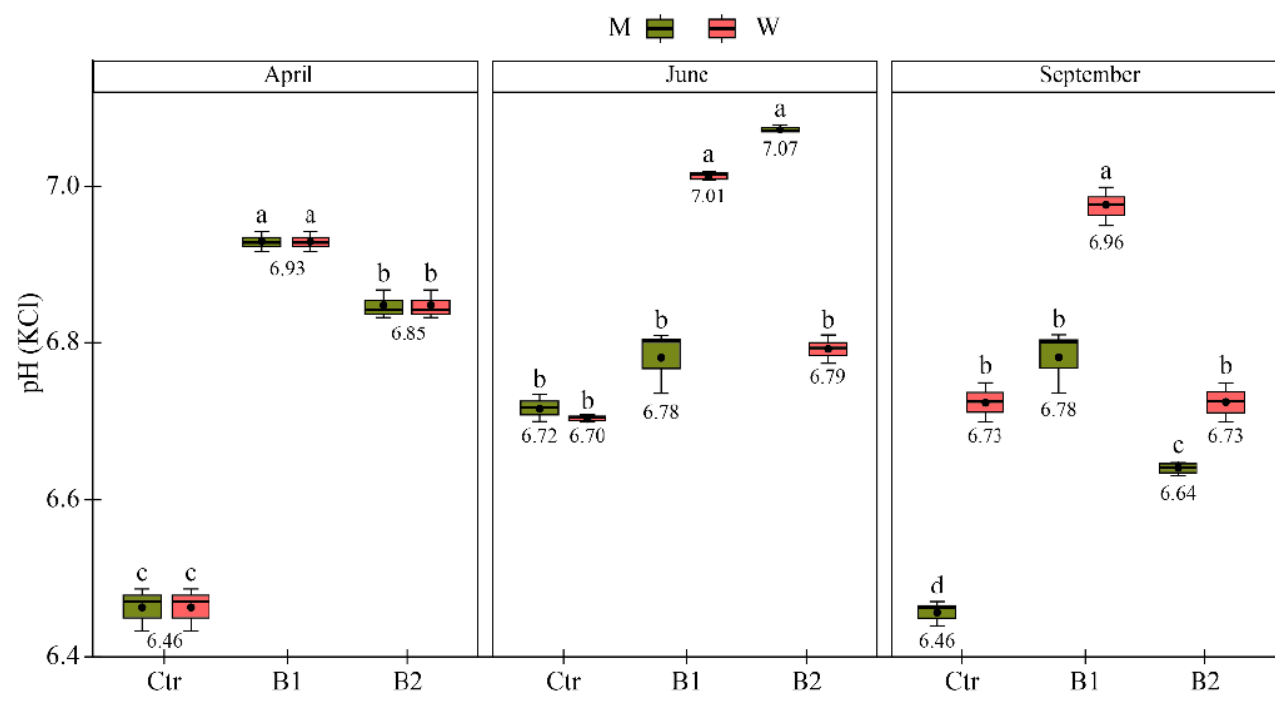

Figure 1. $\mathrm{pH}(\mathrm{KCl})$ changes in the soil during the vegetation season; treatments not sharing one letter are significantly different $(p<0.001)$.

The researched soil had a neutral reaction at the beginning of the experiment: the $\mathrm{pH}(\mathrm{KCl})$ value was 6.46 (Figure 1). When soil amendments were added to the soil, $\mathrm{pH}$ increased to 6.93 for B1 and 6.85 for B2. This trend is following literature data [58] when adding biochar led to alkalization of the soil.

With vegetation, the soil's pH slightly decreased. In particular, it was in September for system B2. For system W (without crop), the $\mathrm{pH}$ did not change (within the statistical difference). The decreasing of $\mathrm{pH}$ can be due to taking alkaline elements ( $\mathrm{Ca}$ and $\mathrm{Mg}$ ) by the plant during its development.

The incorporation of biochar into the soil enriched it for nitrogen; specifically, B1 enriched the soil for ammonium nitrogen, while B2 mainly enriched the content of nitrate nitrogen. During crop's growing, the nitrogen content in both forms decreased in the soil; in particular, this decreasing was observed for nitrogen nitrates. This trend is typical for different plants' vegetation due to nitrogen's good availability to the plant during the growing period $[59,60]$. In our case, the availability of nitrogen was higher, while B2 was presented in the system. The observed increase of $\mathrm{NO}_{3}$ concentration in July compared to April ensured the active elaboration of nitrogen from both amendments and nitrification of ammonium nitrogen thanks to intensive microbiological activities [59]. The prevalence of using $\mathrm{NO}_{3}$ nitrogen during the plant's development was also pointed because the content of ammonium nitrogen did not change significantly during the experiment: this can be explained by less ammonium nitrogen in the plant [60]. Moreover, the higher content of 
$\mathrm{NH}_{4}$ in the soil with plants compared to the soil without plants showed its less active role in plant's development and soil microbes in the rhizosphere, promoting the accumulation of $\mathrm{NH}_{4}$ in the soil [59].

The phosphorus concentration was higher at the initial soil amended with B2 compared with control because B2 had phosphorus in the content. However, amending the initial soil by B1 did not increase this element (Figure 2c). With vegetation, the phosphorus transformed to a more available form, and its content increased for the soil amended by B1 caused by intensive usage of phosphorus by the plant for the development. As a result, in September, the soil's phosphorus content decreased for the system with plant and B1; in the system without plant, phosphorus was still available in the soil. The phosphorus availability was higher for the soil with B2 than for B1, and its content decreased started from June to September.
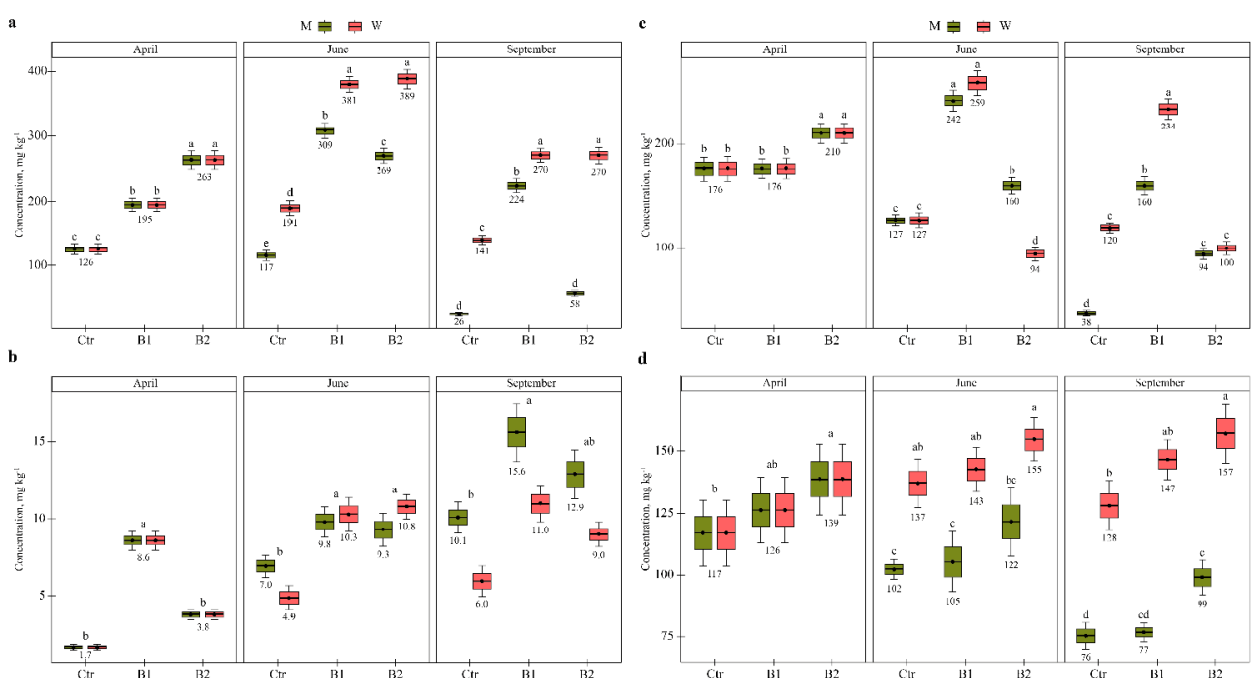

Figure 2. Soil parameters changes during $\mathrm{M} . \times$ giganteus growing in uncontaminated soil $\left(\mathrm{A}=0 \mathrm{mg} \mathrm{kg}^{-1}\right):\left(\right.$ a) $\mathrm{NO}_{3}$ ( $p<0.001)$; (b) $\mathrm{NH}_{4}$ ( $p<0.001$ for difference between statistical groups, namely between $\mathrm{Ctr}, \mathrm{B} 1$ and $\left.\mathrm{B} 2\right)$; (c) $\mathrm{P}_{2} \mathrm{O}_{5}(p<0.001)$; (d) K (April: $p<0.05$; June: $p<0.001$; September: $p<0.001$ ); treatments not sharing one letter are significantly different.

Adding amendments to the initial soil increased the potassium's content in both cases; however, the effect was higher for B2 (Figure 2d). Results showed that $M . \times$ giganteus used this element during growing because potassium's content decreased starting from June, then the effect was evident for September due to a fewer utilization of this element by the plant.

During growth, $M . \times$ giganteus intensively uptakes nutrients having broad roots' structure $[55,56]$. The data received in the current study confirmed that fact because the concentration of $\mathrm{NO}_{3}, \mathrm{P}_{2} \mathrm{O}_{5}$ and $\mathrm{K}$ decreased in the soil with growing $M . \times$ giganteus compared to the soil without the plant. Indeed, the content of $\mathrm{NH}_{4}$ increased consistently to the end of vegetation, which showed its less active role in $M . \times$ giganteus development. The increase may be additionally caused by soil microbes' activities in the plant's rhizosphere promoting the accumulation of $\mathrm{NH}_{4}$ in the soil [6]. That is why it is recommended to compensate for the nutrient uptake by fertilizers when the crop was cultivated multiyear in the field conditions; nevertheless, the nutrient requirements of $M . \times$ giganteus are low than other crops [61].

\subsection{Impact of Soil Contamination by Diesel to M. $\times$ giganteus Bioparameters}

The soil contamination by hydrocarbons leads to profound changes in soil properties, i.e., deterioration of water-air and physicochemical properties, absorption capacity, and reduced reserves of mineral nutrients, which overall violated soil fertility [62]. The hydrocarbons can hinder the uptakes of nutrients and water from the soil by plants [63], cause 
their bio-membrane injury by leading to accumulation of reactive oxygen species [64], and inhibit the photosynthesis and transpiration [65].

The phytotoxicity of the diesel-contaminated soil increases with the level of contamination, and extreme contamination levels can finally lead to plant death and the degradation of plant communities [22,66].

The remediation of hydrocarbon contaminated soil is still a growing technology that is rather often used co-bioremediation of plants and microbes $[67,68]$.

Earlier, $M . \times$ giganteus showed proper development in the organics contaminated soils [28] supported by soil amendments. In the current study, applying this crop to the diesel-contaminated soils was explored, including the cases when biochars amended the soil.

The dynamic of bioparameters during $M . \times$ giganteus growing in the diesel-contaminated soils with biochar's amendments is presented in Figure 3 (for the height of plant), Figure S1 (for the leaves quantity) and Figure 4 (for leaf blade area).

As expected, with increasing the level of soil contamination by diesel, the plant's parameter (height) decreased (Figure 3), and the most significant deterioration in the plant's development was determined for the highest level of diesel contamination (marked as E). Same time at the small concentrations of soil contamination (experiment B and C), the parameters of $M . \times$ giganteus were similar to those observed for the control soil (A). It may be concluded that $M . \times$ giganteus may successfully be applied to the diesel-contented soil in a range of contamination concentrations $0-1000 \mathrm{mg} \mathrm{kg}^{-1}$ because those doses of contamination disturb the plant's development insignificantly. The soil contamination's negative impact was neglected when biochar was incorporated into the system; the plant height in September for cases B and C was similar to A in the presence of B1 and B2.

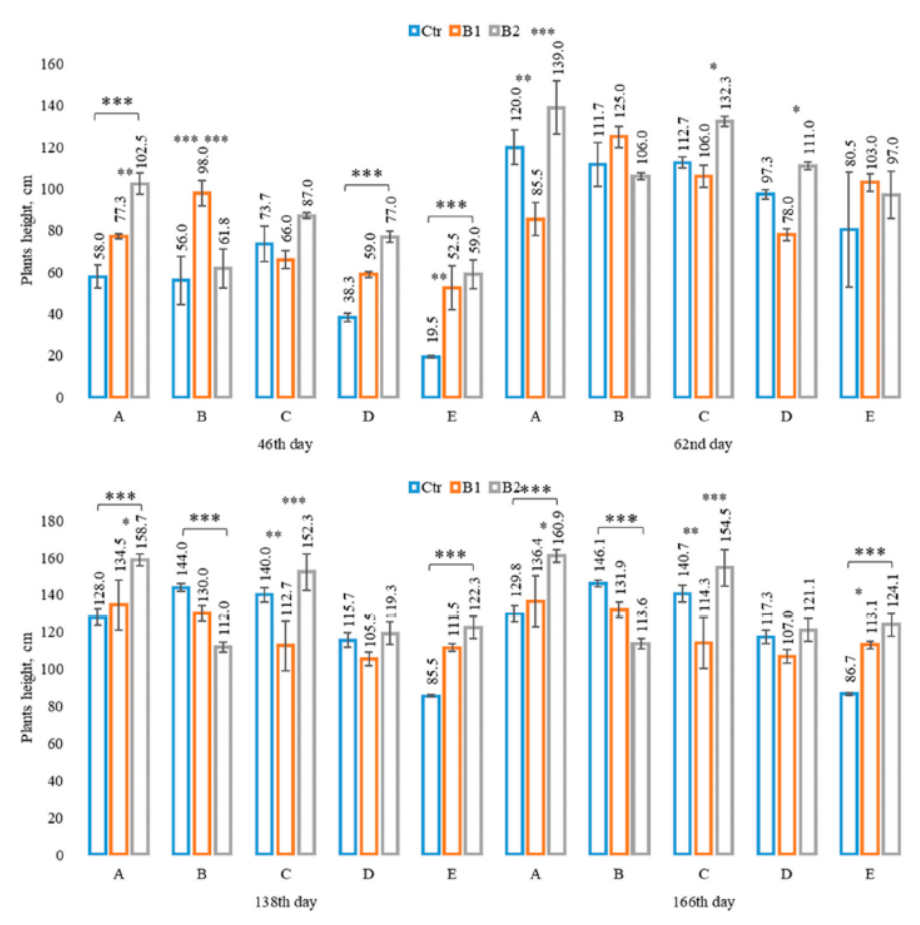

Figure 3. Growth dynamic of M. $\times$ giganteus during vegetation season. Asterisks denote the significant difference between compared pairs $\left({ }^{*}-p<0.05 ;{ }^{* *}-p<0.01\right.$; ${ }^{* *}-p<0.001$ ). (A) Diesel concentration in soil was $0 \mathrm{mg} \mathrm{kg}^{-1}$; (B) diesel concentration in soil was $250 \mathrm{mg} \mathrm{kg}^{-1}$; (C) diesel concentration in soil was $1000 \mathrm{mg} \mathrm{kg}^{-1}$; (D) diesel concentration in soil was $3000 \mathrm{mg} \mathrm{kg}^{-1}$; (E) diesel concentration in soil was $5000 \mathrm{mg} \mathrm{kg}^{-1}$.

The morphological characteristics of $M . \times$ giganteus when the plant was cultivated in the traditional agricultural land showed a close correlation between height and weight of the shoots, numbers of leaves in each shoot and surface of the leaves [69]. Current research 
confirmed this correlation (Figure 3, Figure 4 and Figure S1) when an essential impact of the soil contamination on the morphological parameters was detected. In the experiment without contamination (A), the increasing number of leaves was observed during vegetation; at the highest diesel concentration in the soil (E), the number of leaves decreased at the end of vegetation (September), the same trend was seen for the plant's height (Figure 3). In summary, the presence of B1 and B2 in the soil protected the plant's development.

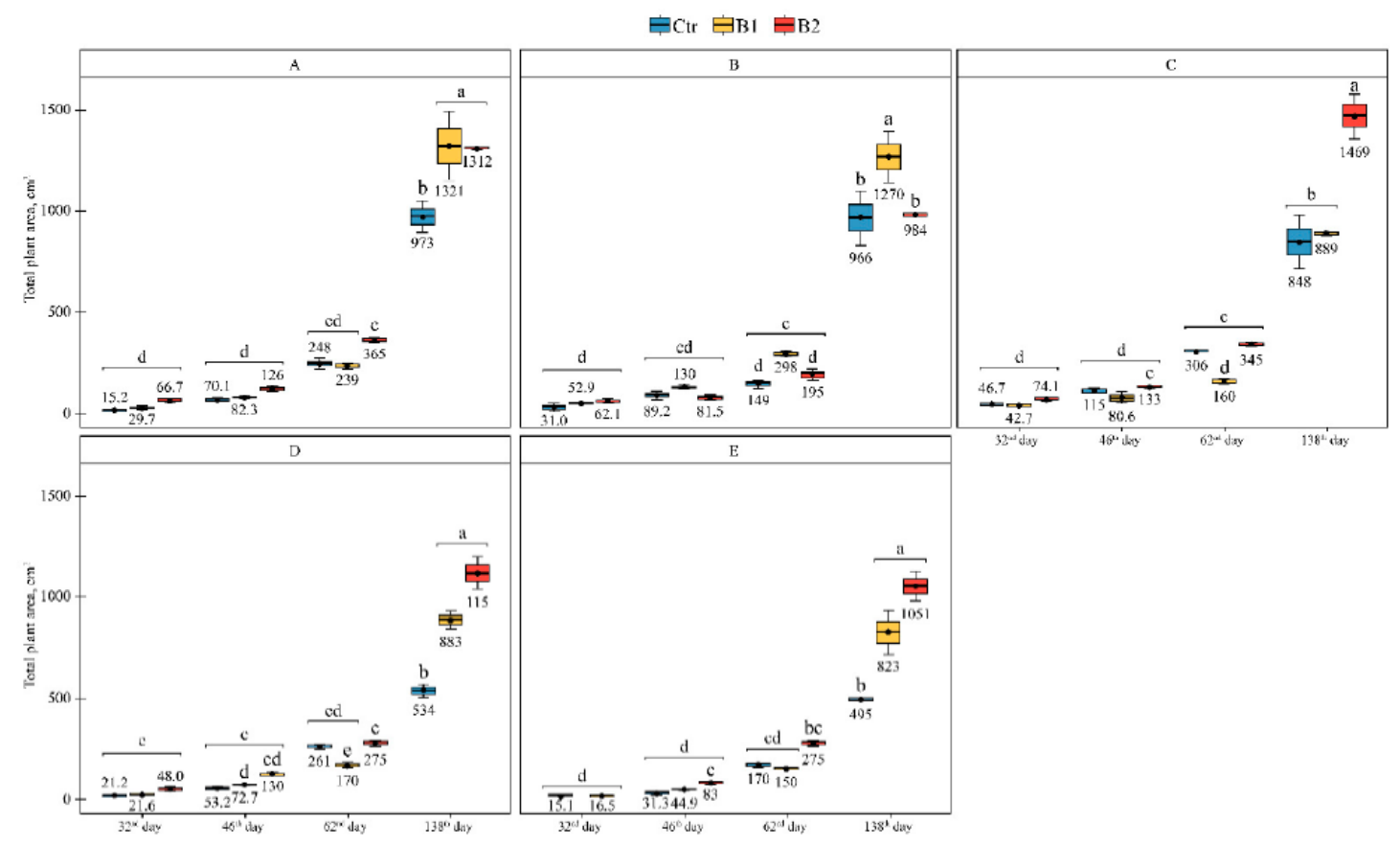

Figure 4. Total plant's surface area as changed during vegetation season. (A) Diesel concentration in the soil was $0 \mathrm{mg}^{\mathrm{kg}} \mathrm{k}^{-1}$; (B) diesel concentration in the soil was $250 \mathrm{mg} \mathrm{kg}^{-1}$; (C) diesel concentration in the soil was $1000 \mathrm{mg} \mathrm{kg}^{-1}$; (D) diesel concentration in the soil was $3000 \mathrm{mg} \mathrm{kg}^{-1}$; (E) diesel concentration in the soil was $5000 \mathrm{mg} \mathrm{kg}^{-1}$. Treatments not sharing one letter are significantly different $(p<0.001)$.

Nevertheless, the number of leaves decreased with the increase of soil contamination. The decrease itself was slower when amendments were added (Figure S1). In September, the leaves' number of experiment B was $25.0 \%$ higher with B1 and $21.9 \%$ higher with B2 than $C$ tr. For experiment $C$, these numbers were highest at $15.9 \%$ and $21.7 \%$, respectively, and for experiment $\mathrm{D}$, these numbers were highest at $43.0 \%$ and $27.1 \%$, respectively.

The number of $M . \times$ giganteus leaves was connected with their surface having a correlation coefficient equal to $7.76 \pm 0.07$ [69]. The $M . \times$ giganteus leaves' surface was calculated using the approach described at Kvak et al. [70] and presented in Figure 4. The leaves' surface was less affected by the small diesel concentrations in the soil (B, C), and the effect was more evident with the higher concentrations ( $D$ and E). Conversely, in the presence of B1 and B2, this decrease was less significant.

Incorporating B1 and B2 into the soil without contamination increased the value of the harvested aboveground biomass compared to the Ctr (Figure S2), which is following published results when biochar was used in combination with fertilizes during cultivation of $M . \times$ giganteus in the agricultural land [32].

The results of harvested dry biomass (leaves and stems separately, as well as their sum) as impacted by biochars are presented in Figure S2, and as impacted by different concentrations of diesel in the soil amended by B1 and B2 are presented in Figure 5.

Results illustrated that level of contamination affected the dry biomass of stems more essential compared with leaves. This trend was evident at the high concentration of diesel (experiment $\mathrm{D}$ and $\mathrm{E}$ ). At the small concentration, the harvested biomass value was similar 
to Ctr. For almost all experiments, the biochars' incorporation increased the harvest value, as demonstrated in [32].
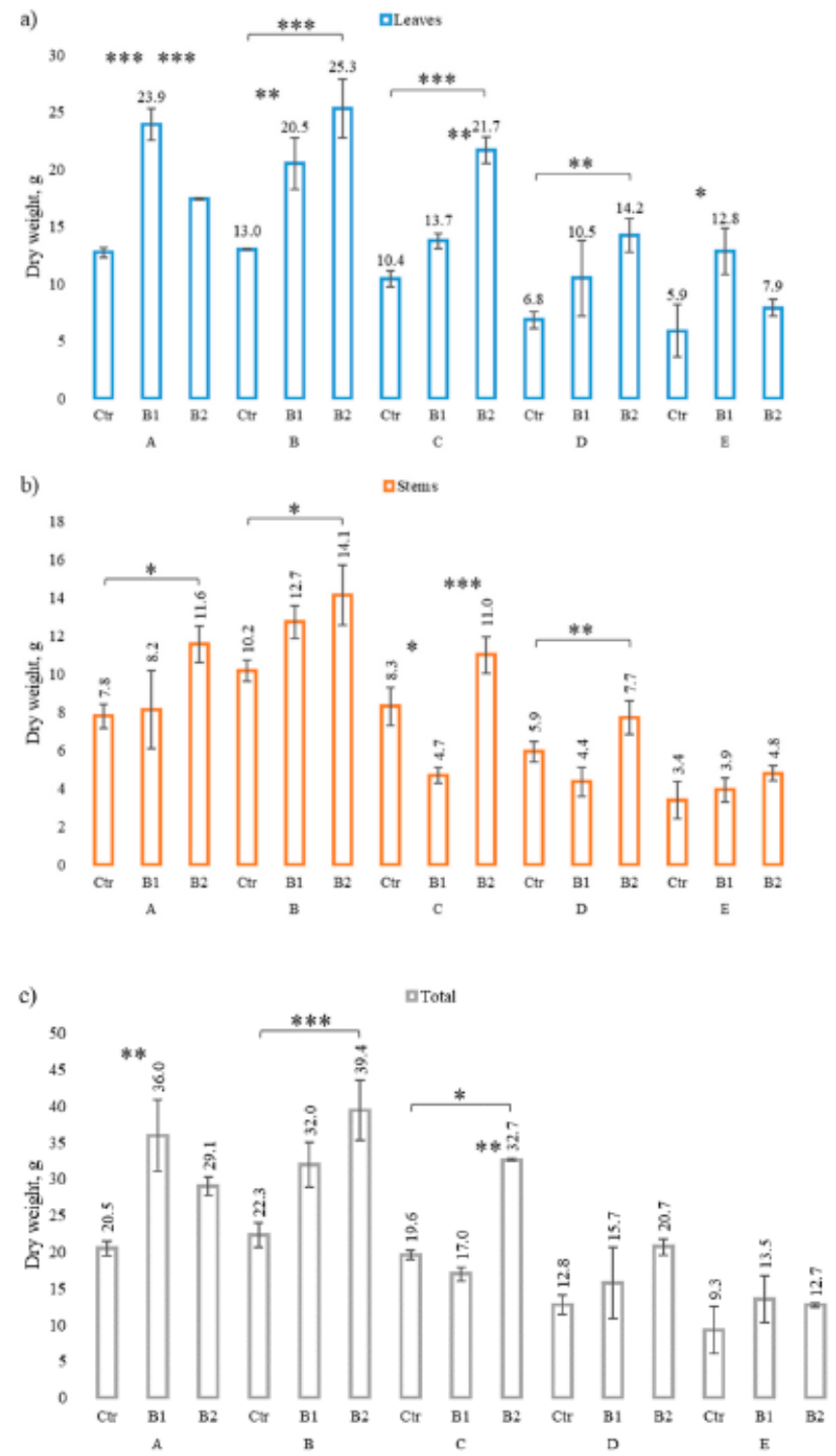

Figure 5. Dry weight of $M . \times$ giganteus aboveground biomass at harvest: (a) leaves; (b) stems; (c) total aboveground biomass. Asterisks denote the significant difference between compared pairs $\left({ }^{*}-p\right.$ $<0.05$; ${ }^{* *}-p<0.01 ; * *-p<0.001$ ). (A) Diesel concentration in the soil was $0 \mathrm{mg} \mathrm{kg}^{-1}$; (B) diesel concentration in the soil was $250 \mathrm{mg} \mathrm{kg}^{-1}$; (C) diesel concentration in the soil was $1000 \mathrm{mg} \mathrm{kg}^{-1}$; (D) diesel concentration in the soil was $3000 \mathrm{mg} \mathrm{kg}^{-1}$; (E) diesel concentration in the soil was $5000 \mathrm{mg} \mathrm{kg}^{-1}$.

While comparing the impact of soil amending by biochar to the plant height at the same diesel concentration (Figure 6, Table S1), B2 showed a different influence than B1 and Ctr. For the earlier development stage (May and June), the amendment by B1 did not show any effect. 


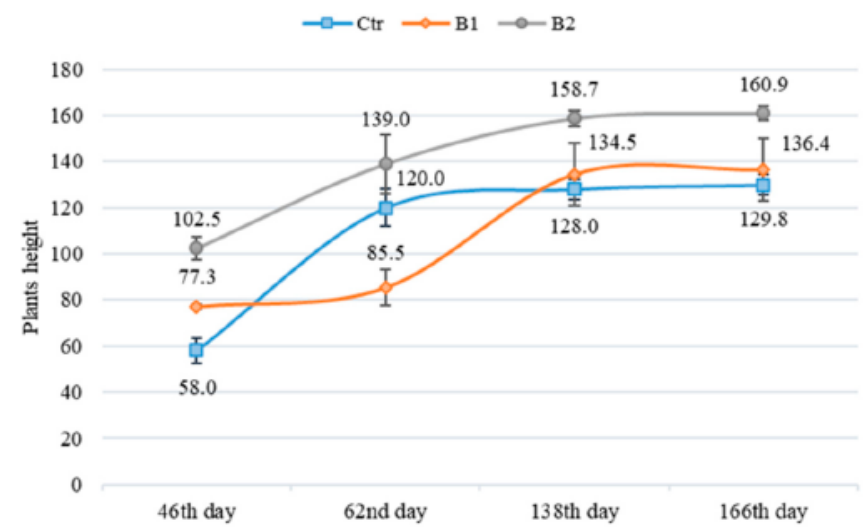

Figure 6. Growth dynamic of $M . \times$ giganteus in uncontaminated soil amended by biochars.

\subsection{Impact of Soil Amendment by Biochar and Contamination by Diesel to the Plant State}

The photosynthesis of plants growing in the hydrocarbons contaminated soils was inhibited due to induced toxicities to living cells by contaminants [71]. The toxic components could be taken via the roots, stem and leaves, which may alter the integrity and permeability of plant membranes leading to disturbance of carbon metabolisms in the leaves, ion and water uptake in the roots [63]. Hydrocarbons' hydrophobic nature prevents water from spreading inhomogeneously in the contaminated soil, resulting in a water deficiency [72].

It is known $[22,50,73]$ that changes in the photosynthetic apparatus (PSA) can be a marker for assessing the plant's overall functional state, the effectiveness of the adaptive plant's reaction and its development as a response to different growing conditions. Each quantum of the light absorbed by pigments can induce the primary charge separation in the photosystem's reaction centers (RC), be dissipated to heat, or be illuminated as a fluorescence quantum. Light energy differs depending on the PSA state, the content of chlorophyll, and the external conditions. The decreasing chlorophyll content in plant leaves due to RC's closure may cause a decrease in the quantum efficiency of photosystem II (PSII). That will inevitably slow down the rate of $\mathrm{CO}_{2}$ assimilation and impairing the effectiveness of PSA. Under such conditions, the extra light energy causes the reactive oxygen species' appearance (ROS), which can inhibit and damage the plant's photosynthetic apparatus [73]. One of the protection mechanisms against oxidative damaging of PSA is NPQt, and increasing NPQt's level ensures the primary message of the light-protective reaction for the prevention or reduction of the ROS negative effect the primary level of photosynthesis.

In the current study, the stress response of $M . \times$ giganteus grown in the dieselcontaminated soils was evaluated with and without soil amendments. For this reason, the changes of physiological parameters, i.e., NPQt and the SPAD, were determined in the different phases of $M . \times$ giganteus vegetation followed the approach described at $[51,53]$. Results are presented in Figure 7 and Figure S3.

It may be concluded that SPAD changes in plant leaves during vegetation in the Ctr soil without amendments increased in the summer month (June, August) and decreased in September when the first signs of plants wilting appeared with fixed yellow leaves. These peculiarities are typical for the plant's development $[74,75]$ and illustrated earlier when the photosynthesis of Amorpha fruticosa seedlings to different concentrations of petroleum-contaminated soils was measured during vegetation from April to September [76]. However, in our case, when B1 or B2 was amended to the soil, the SPAD was still high in September. The SPAD of B1 was higher in September than in the summer months, while the SPAD of B2 was equal during the summer months and September. Such observation permits us to conclude that incorporating B1 and B2 into the uncontaminated soil increased the vegetation period's duration. 


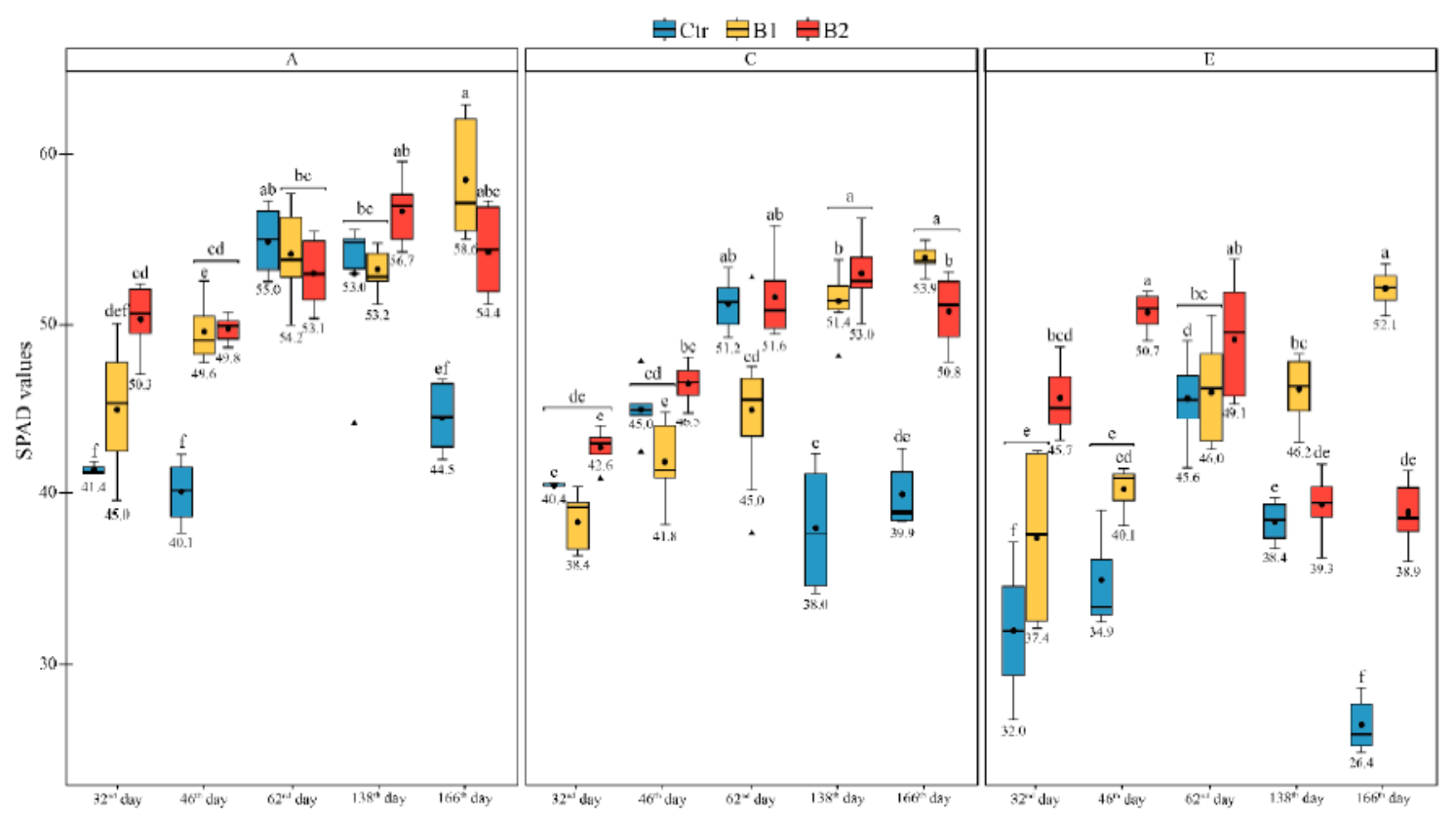

Figure 7. M. $\times$ giganteus SPAD changes during vegetation. (A) Diesel concentration in soil was $0 \mathrm{mg} \mathrm{kg}^{-1}$; (C) diesel concentration in soil was $1000 \mathrm{mg} \mathrm{kg}^{-1}$; (E) diesel concentration in soil was $5000 \mathrm{mg} \mathrm{kg}^{-1}$. Treatments not sharing one letter are significantly different $(p<0.001)$.

In the case of middle contaminated soil C (concentration of diesel $1000 \mathrm{mg} \mathrm{kg}^{-1}$ ), the SPAD parameter was much higher in the amended soil (for B1 and B2) than Ctr soil; the withering of the plant was fixed for Ctr soil even in August with decreasing of the SPAD.

In the case of the highest contaminated soil $\mathrm{E}$ (concentration of diesel $5000 \mathrm{mg} \mathrm{kg}^{-1}$ ), the first sight of plant's withering accompanied with the decreasing of the SPAD was evident even in June for the Ctr soil without amendment, while in the presence of biochar the first sight of withering was postponed to August for B2 and the plant started to wilt only after August. In the case of B1, the SPAD was relatively stable during summer, and in September, it was even a little higher. That fact clearly shows that incorporating B1 or B2 into the system protected the plant from the stress caused by the high diesel concentration in the soil and prevented plants from earlier withering. The incorporating biochar into the diesel-contaminated soil prolonged the vegetation period of $M . \times$ giganteus, and the effect was evident even at the high level of contamination. These results are perspective for crop utilization in diesel contaminated soil because it illustrated a profitable growth and harvest value in a range of contaminated concentration $250-1000 \mathrm{mg} \mathrm{kg}^{-1}$. The plant's development was better in B1 and B2, which stressed the positive effect of carbon contented amendments to $M . \times$ giganteus cultivation in the diesel-contaminated soil.

During the vegetation period in the plants growing in the control or contaminated soils, the SPAD monitoring showed differences in the dynamic of green pigment's content and its concrete values [74,75].

In the current study, with applying B1 or B2, the level of NPQt in the light-harvesting complex (LHCII) of $M$. $\times$ giganteus significantly decreased (Figure S3). This fact indicated a decrease in sharing of the thermal energy dissipation in the LHCII of PSII and accordingly illustrated energy utilization improvement. Based on this hypothesis, we assumed an increase in the efficiency of excitation energy transfer between the pigments of LHCII and RC of PSII [77]. Ultimately, the detected positive effect of biochar on photosynthesis can be a prerequisite for increasing $M . \times$ giganteus biomass productivity, including the case when the crop was cultivated in the diesel-contaminated soils.

Based on three indexes, i.e., biomass at harvest, the SPAD and NPQt, the positive effect of biochar incorporation on the plant's development was noticed. In particular, the effect was distinguishable for B1: when the plant was grown in soil amended by B1, it was 
characterized by the highest SPAD value, the lowest NPQt value that logistically resulted in the highest productivity at harvest.

With B1 and B2, the negative effect of soil contamination by diesel to PSA parameter was lower for all diesel-contamination concentrations, and the effect of B2 was more potent than for B1. At the highest contamination level equal to $5000 \mathrm{mg} \mathrm{kg}^{-1}$, adding B1 ensured the growing condition, which kept the relative level of SPAD over 40. Nevertheless, the productivity of $M . \times$ giganteus was lower compared to the control. Starting from August, the SPAD parameter was below 40 , followed by decreasing $M . \times$ giganteus morphometric parameters [78]. When the plant grew in amended soil, the increasing value of the SPAD in leaves may be due to additional nitrogen contribution to the soil with biochar.

Thus, an essential character of $M . \times$ giganteus growing in the diesel contaminated soil was the low-level chlorophyll in the mesophilic cells of leaf and high dissipation of light energy in heat through the mechanism of NPQt. This feature is a good illustration of the adaptive $M . \times$ giganteus strategy, allowing good vegetation even when the crop was developed in severe soil contamination conditions. One mitigation action for proper M. $\times$ giganteus production in the diesel-contaminated soil is amending that soil by biochar.

\section{Conclusions}

The greenhouse experiment with the diesel-contaminated soils in a range of $250-5000 \mathrm{mg} \mathrm{kg}^{-1}$ showed sufficient $M . \times$ giganteus development during vegetation. When two biochars enriched the soil: B1 (received from wastewater sludge) and B2 (received from the mixture of wood biochar and biohumus), the plant illustrated profitable growth. Results showed that incorporating B1 and B2 enriched the soil with nutrients, prolonged the plant's vegetation period, improved the crop's morphological and physiological parameters. The surface of $M . \times$ giganteus leaves was less affected by the small diesel concentrations in the soil, and the effect was evident with the higher level of contaminations; in the presence of biochars, this leaves' decreasing was not as prominent.

Based on the SPAD and NPQt values and harvested biomass parameters, biochar's positive effect was illustrated, which was more visible for B1: plant growing in this soil had the highest SPAD and lowest NPQt values, which logistically resulted in the highest productivity at harvest. The physiological parameters analysis illustrated that incorporating carbon-contented amendments decreased the plant's stress and prolonged vegetation.

The growing of $M . \times$ giganteus in the uncontaminated soil changed its parameters: with vegetation, the content of $\mathrm{NO}_{3}$ and $\mathrm{K}$ decreased, which is a typical process occurring during plants' development; the content of $\mathrm{NH}_{4}$ increased, more evidently due to soil microbes' activity in the plant's rhizosphere; the content of $\mathrm{P}_{2} \mathrm{O}_{5}$ increased for summer months and decreased in autumn because of the phosphorus transformation into more available for plants form. The incorporation of biochars increased the soil $\mathrm{pH}$; with vegetation, the value slightly decreased due to the alkaline elements' (Ca and $\mathrm{Mg}$ ) uptake during vegetation.

An essential feature of $M . \times$ giganteus grown in the diesel-contaminated soil was the low chlorophyll level in the leaf's mesophilic cells and high dissipation of light energy into the heat of the NPQt mechanism. This is an important illustration of the M. $\times$ giganteus adaptive strategy, which ensures good vegetation, even if the crop was grown in highly diesel-contaminated soil; the effect was more essential in the presence of biochar. The received results look perspective for using $M . \times$ giganteus to the revitalization of the dieselcontaminated soil. Future research must be focused on studying the biodegradation of hydrocarbons in the diesel-contaminated soils stimulated in the vicinity of $M . \times$ giganteus roots due to the enhancement of microbial biomass activity following root exudation [79].

Supplementary Materials: The following are available online at https: / www.mdpi.com/article/ 10.3390 /agronomy11040798/s1, Figure S1. Leaves quantity changes occurring in M. $\times$ giganteus grown in soil differently contaminated by diesel with amendments. Asterisks denote the significant difference between compared pairs $\left({ }^{*}-p<0.05 ;{ }^{* *}-p<0.01 ;{ }^{* * *}-p<0.001\right)$; Figure S2. Aboveground biomass dry weight of $M . \times$ giganteus grown in uncontaminated soil with the presence of different amendments; Figure S3. M. $\times$ giganteus NPQt photometric parameters changes during one vegetation; 
Table S1. M. $\times$ giganteus height increasing (in percentages), while growing in soil with biochars (B1 and B2); Table S2. MANOVA test results for processing soil parameters changes (T-treatment; ID-presence or absence of M. $\times$ giganteus; M-the month of measurements; ges-generalized eta squared); Table S3. MANOVA test results for processing $M . \times$ giganteus physiological parameters changes ( $\mathrm{T}$ - treatment; $\mathrm{M}$ - the month of measurements; $\mathrm{C}$-contamination level; ges—generalized eta squared; DW—dry weight).

Author Contributions: Conceptualization, V.P.; methodology, A.H., V.K. and O.K.; software, A.M.; validation, A.H., V.K. and O.K.; formal analysis, V.P. and A.M.; investigation, V.P., A.H., V.K. and O.K.; resources, V.P. and A.H.; data curation, V.P.; writing-original draft preparation, V.P.; writingreview and editing, V.P., A.H., V.K., O.K., A.M. and S.U.; visualization, A.M.; supervision, V.P.; project administration, A.H.; funding acquisition, V.P. and A.H. All authors have read and agreed to the published version of the manuscript.

Funding: This research was funded by NATO SPS MYP G4687, Czech-German CORNET project "MiscanValue" and project CACTU, Reg. No. CZ.02.1.01/0.0/0.0/17_049/0008397, co-financed by European Union from the European Regional Development Fund through the Operational Programmer Research, Development and Education.

Acknowledgments: The research was supported by NATO SPS MYP G4687, Czech-German CORNET project "MiscanValue" and project CACTU, Reg. No. CZ.02.1.01/0.0/0.0/17_049/0008397, co-financed by European Union from the European Regional Development Fund through the Operational Programmer Research, Development and Education. The authors are thankful to Pavlo Shapoval, National University "Lvivska Polytechnika", Ukraine, for providing chemical analysis of initial soil and biochars' content; Karel Prokeš, Almeco, Czech Republic and Volodymyr Kvak, Institute of Energy Crops and Sugar Beets for supplying the biochars, and to Ethan Nicolas Duong, Canada for assistance with the English style proofreading.

Conflicts of Interest: The authors declare no conflict of interest. The funders had no role in the design of the study; in the collection, analyses, or interpretation of data; in the writing of the manuscript, or in the decision to publish the results.

\section{References}

1. Rodríguez-Eugenio, N.; McLaughlin, M.; Pennock, D. Soil Pollution: A Hidden Reality; Food and Agriculture Organization of the United Nations: Rome, Italy, 2018.

2. Okere, U.; Semple, K. Biodegradation of PAHs in 'Pristine'Soils from Different Climatic Regions. J. Bioremed. Biodegrad. 2012, S1, 6. [CrossRef]

3. Korchagina, L. Features of plants growing in upland bogs in the conditions of oil pollution in the middle Ob's region. News Nizhnevartovsk State Univ. Math. Nat. Sci. 2015, 1,8.

4. Roy, S.; Labelle, S.; Mehta, P.; Mihoc, A.; Fortin, N.; Masson, C.; Leblanc, R.; Châteauneuf, G.; Sura, C.; Gallipeau, C.; et al. Phytoremediation of Heavy Metal and PAH-Contaminated Brownfield Sites. Plant Soil 2005, 272, 277-290. [CrossRef]

5. Podan, I.; Dzura, N. Impact of Oil Contamination and Humates to the Development of Miscanthus Plants. Ecol. Sci. 2019, 182-186. [CrossRef]

6. Técher, D.; Martinez-Chois, C.; Laval-Gilly, P.; Henry, S.; Bennasroune, A.; D’Innocenzo, M.; Falla, J. Assessment of Miscanthus $\times$ giganteus for Rhizoremediation of Long Term PAH Contaminated Soils. Appl. Soil Ecol. 2012, 62, 42-49. [CrossRef]

7. Gerhardt, K.E.; Huang, X.-D.; Glick, B.R.; Greenberg, B.M. Phytoremediation and Rhizoremediation of Organic Soil Contaminants: Potential and Challenges. Plant Sci. 2009, 176, 20-30. [CrossRef]

8. Susarla, S.; Medina, V.F.; McCutcheon, S.C. Phytoremediation: An Ecological Solution to Organic Chemical Contamination. Ecol. Eng. 2002, 18, 647-658. [CrossRef]

9. Zhang, C.; Feng, Y.; Liu, Y.; Chang, H.; Li, Z.; Xue, J. Uptake and Translocation of Organic Pollutants in Plants: A Review. J. Integr. Agric. 2017, 16, 1659-1668. [CrossRef]

10. Brosse, N.; Dufour, A.; Meng, X.; Sun, Q.; Ragauskas, A. Miscanthus: A Fast-Growing Crop for Biofuels and Chemicals Production. Biofuels Bioprod. Biorefining 2012, 6, 580-598. [CrossRef]

11. McCalmont, J.P.; Hastings, A.F.S.J.; McNamara, N.P.; Richter, G.M.; Robson, P.; Donnison, I.S.; Clifton-Brown, J.C. Environmental Costs and Benefits of Growing Miscanthus for Bioenergy in the UK. GCB Bioenergy 2015, 9, 489-507. [CrossRef]

12. Nsanganwimana, F.; Pourrut, B.; Mench, M.; Douay, F. Suitability of Miscanthus Species for Managing Inorganic and Organic Contaminated Land and Restoring Ecosystem Services. A Review. J. Environ. Manag. 2014, 143, 123-134. [CrossRef]

13. Wanat, N.; Austruy, A.; Joussein, E.; Soubrand, M.; Hitmi, A.; Gauthier-Moussard, C.; Lenain, J.-F.; Vernay, P.; Munch, J.C.; Pichon, M. Potentials of Miscanthus $\times$ giganteus Grown on Highly Contaminated Technosols. J. Geochem. Explor. 2013, 126-127, 78-84. [CrossRef] 
14. Pidlisnyuk, V.; Stefanovska, T.; Lewis, E.E.; Erickson, L.E.; Davis, L.C. Miscanthus as a Productive Biofuel Crop for Phytoremediation. Crit. Rev. Plant Sci. 2014, 33, 1-19. [CrossRef]

15. Andrejić, G.; Šinžar-Sekulić, J.; Prica, M.; Dželetović, Ž.; Rakić, T. Phytoremediation Potential and Physiological Response of Miscanthus $\times$ giganteus Cultivated on Fertilized and Non-Fertilized Flotation Tailings. Environ. Sci. Pollut. Res. 2019, 26, 34658-34669. [CrossRef]

16. Cosentino, S.L.; Scordia, D.; Testa, G.; Monti, A.; Alexopoulou, E.; Christou, M. 1-The Importance of Perennial Grasses as a Feedstock for Bioenergy and Bioproducts. In Perennial Grasses for Bioenergy and Bioproducts; Alexopoulou, E., Ed.; Academic Press: Cambridge, MA, USA, 2018; pp. 1-33. ISBN 978-0-12-812900-5.

17. Lewandowski, I.; Clifton-Brown, J.; Kiesel, A.; Hastings, A.; Iqbal, Y. 2-Miscanthus. In Perennial Grasses for Bioenergy and Bioproducts; Alexopoulou, E., Ed.; Academic Press: Cambridge, MA, USA, 2018; pp. 35-59. ISBN 978-0-12-812900-5.

18. Roik, M.; Sinchenko, V.; Purkin, V.; Kvak, V.; Humentik, M. (Eds.) Miscanthus in Ukraine; FOP Yamchinskiy Press: Kyiv, Ukraine, 2019; ISBN 978-617-7804-11-5.

19. Pidlisnyuk, V.V.; Shapoval, P.; Zgorelec, Z.; Stefanovska, T.; Zhukov, O. Multiyear Phytoremediation and Dynamic of Foliar Metal(Loid)s Concentration during Application of Miscanthus $\times$ giganteus Greef et Deu to Polluted Soil from Bakar, Croatia. Environ. Sci. Pollut. Res. 2020. [CrossRef]

20. Nebeská, D.; Trögl, J.; Pidlisnyuk, V.; Popelka, J.; Veronesi Dáňová, P.; Ust'ak, S.; Honzík, R. Effect of Growing Miscanthus $\times$ giganteus on Soil Microbial Communities in Post-Military Soil. Sustainability 2018, 10, 4021. [CrossRef]

21. Técher, D.; Laval-Gilly, P.; Henry, S.; Bennasroune, A.; Formanek, P.; Martinez-Chois, C.; D’Innocenzo, M.; Muanda, F.; Dicko, A.; Rejšek, K.; et al. Contribution of Miscanthus $\times$ giganteus Root Exudates to the Biostimulation of PAH Degradation: An in Vitro Study. Sci. Total Environ. 2011, 409, 4489-4495. [CrossRef]

22. Nebeská, D.; Auer Malinská, H.; Erol, A.; Pidlisnyuk, V.; Kuráň, P.; Medžová, A.; Smaha, M.; Trögl, J. Stress Response of Miscanthus Plants and Soil Microbial Communities: A Case Study in Metals and Hydrocarbons Contaminated Soils. Appl. Sci. 2021, 11, 1866. [CrossRef]

23. Ciarkowska, K.; Gambus, F.; Antonkiewicz, J.; Koliopoulos, T. Polycyclic Aromatic Hydrocarbon and Heavy Metal Contents in the Urban Soils in Southern Poland. Chemosphere 2019, 229, 214-226. [CrossRef]

24. Ptaszek, N.; Pacwa-Płociniczak, M.; Noszczyńska, M.; Płociniczak, T. Comparative Study on Multiway Enhanced Bio- and Phytoremediation of Aged Petroleum-Contaminated Soil. Agronomy 2020, 10, 947. [CrossRef]

25. Antonkiewicz, J.; Kołodziej, B.; Bielińska, E.J.; Popławska, A. The Possibility of Using Sewage Sludge for Energy Crop Cultivation Exemplified by Reed Canary Grass and Giant Miscanthus. Soil Sci. Annu. 2019, 70, 21-33. [CrossRef]

26. Kharytonov, M.; Pidlisnyuk, V.; Stefanovska, T.; Babenko, M.; Martynova, N.; Rula, I. The Estimation of Miscanthus $\times$ giganteus Adaptive Potential for Cultivation on the Mining and Post-Mining Lands in Ukraine. Environ. Sci. Pollut. Res. 2019, 26, $2974-2986$. [CrossRef] [PubMed]

27. Alasmary, Z.; Todd, T.; Hettiarachchi, G.M.; Stefanovska, T.; Pidlisnyuk, V.; Roozeboom, K.; Erickson, L.; Davis, L.; Zhukov, O. Effect of Soil Treatments and Amendments on the Nematode Community under Miscanthus Growing in a Lead Contaminated Military Site. Agronomy 2020, 10, 1727. [CrossRef]

28. Mamirova, A.; Pidlisnyuk, V.; Amirbekov, A.; Ševců, A.; Nurzhanova, A. Phytoremediation Potential of Miscanthus sinensis And. in Organochlorine Pesticides Contaminated Soil Amended by Tween 20 and Activated Carbon. Environ. Sci. Pollut. Res. 2021, 28, 16092-16106. [CrossRef]

29. Pidlisnyuk, V.V.; Erickson, L.; Stefanovska, T.; Popelka, J.; Hettiarachchi, G.; Davis, L.; Trögl, J. Potential Phytomanagement of Military Polluted Sites and Biomass Production Using Biofuel Crop Miscanthus $\times$ giganteus. Environ. Pollut. 2019, 249 , 330-337. [CrossRef]

30. Crane-Droesch, A.; Abiven, S.; Jeffery, S.; Torn, M.S. Heterogeneous Global Crop Yield Response to Biochar: A Meta-Regression Analysis. Environ. Res. Lett. 2013, 8, 044049. [CrossRef]

31. Kloss, S.; Zehetner, F.; Wimmer, B.; Buecker, J.; Rempt, F.; Soja, G. Biochar Application to Temperate Soils: Effects on Soil Fertility and Crop Growth under Greenhouse Conditions. J. Plant Nutr. Soil Sci. 2014, 177, 3-15. [CrossRef]

32. Saletnik, B.; Zagula, G.; Bajcar, M.; Czernicka, M.; Puchalski, C. Biochar and Biomass Ash as a Soil Ameliorant: The Effect on Selected Soil Properties and Yield of Giant Miscanthus (Miscanthus $\times$ giganteus). Energies 2018, 11, 2535. [CrossRef]

33. FAO. World Reference Base for Soil Resources 2014: International Soil Classification Systems for Naming Soils and Creating Legends for Soil Maps (Update 2015); World Soil Resources: Rome, Italy, 2014.

34. DSTU 4287:2004. Soil Quality. Sampling; DP “UkrNDNC": Kyiv, Ukraine, 2005; p. 9.

35. Tóth, G.; Hermann, T.; Da Silva, M.R.; Montanarella, L. Heavy Metals in Agricultural Soils of the European Union with Implications for Food Safety. Environ. Int. 2016, 88, 299-309. [CrossRef]

36. Dstu Iso 11464:2007. Soil Quality. Pretreatment of Samples for Physico-Chemical Analyses; DP “UkrNDNC": Kyiv, Ukraine, 2009; p. 12.

37. Kvak, V. Optimization of Elements of Technology for Production Miscanthus for Energy Fuel in the Western Part of Ukrainian Forest-Step. Ph.D. Thesis, Institute of Bioenergy Crops and Sugar Beets, Kyiv, Ukraine, 2014.

38. DSTU 7688:2015. Diesel Fuel Euro; DP “UkrNDNC”: Kyiv, Ukraine, 2015; p. 16.

39. GOST 9965-76. Petroleum for Oil-Processing Plants. Specifications; Standardinform: Moscow, Russia, 1977 ; p. 82. 
40. Wyszkowska, J.; Kucharski, J.; Waldowska, E. The Influence of Diesel Oil Contamination on Soil Microorganisms and Oat Growth. Rostl. Vyrob. 2002, 48, 51-57. [CrossRef]

41. Houben, D.; Evrard, L.; Sonnet, P. Beneficial Effects of Biochar Application to Contaminated Soils on the Bioavailability of Cd, Pb and $\mathrm{Zn}$ and the Biomass Production of Rapeseed (Brassica Napus L.). Biomass Bioenergy 2013, 57, 196-204. [CrossRef]

42. MA. Announcement of the Ministry of Agriculture Related Requests to the Fertilizers; Ministry of Agriculture: Prague, Czech Republic, 2000; Volume N474/2000.

43. DSTU EN ISO/IEC 17065. Issued by the System for Environmental Certification and Ecolabelling; DP “UkrNDNC": Kyiv, Ukraine, 2016; Volume Certificate 10156.

44. DSTU 4289:2004. Soil Quality. Methods for Determination of Organic Matter; DP “UkrNDNC”: Kyiv, Ukraine, $2005 ;$ p. 18.

45. DSTU 4725:2007. Soil Quality. Potassium, Ammonium, Nitrate and Chloride Ion Activity Determination by Potentiometeric Method; DP “UkrNDNC": Kyiv, Ukraine, 2008; p. 22.

46. DSTU 4115:2002. Soils. Determination of Mobile Phosphorus and Potassium Compounds by the Modified Chirikov's Method; DP “UkrNDNC": Kyiv, Ukraine, 2003; p. 12.

47. DSTU 7861:2015. Soil Quality. Determination of Exchanges Calcium, Magnesium, Sodium and Potassium in Soil According to Shollenberger in NSC ISSAR Named after Sokolovsky Modification; DP “UkrNDNC": Kyiv, Ukraine, 2016; p. 12.

48. DSTU ISO 10390:2001. Soil Quality. Determination of pH.; DP “UkrNDNC”: Kyiv, Ukraine, 2002; p. 14.

49. Krause, G.H.; Weis, E. Chlorophyll Fluorescence as a Tool in Plant Physiology. Photosynth. Res. 1984, 5, 139-157. [CrossRef]

50. Malinská, H.; Pidlisnyuk, V.; Nebeská, D.; Erol, A.; Medžová, A.; Trögl, J. Physiological Response of Miscanthus $\times$ giganteus to Plant Growth Regulators in Nutritionally Poor Soil. Plants 2020, 9, 194. [CrossRef]

51. Kuhlgert, S.; Austic, G.; Zegarac, R.; Osei-Bonsu, I.; Hoh, D.; Chilvers, M.I.; Roth, M.G.; Bi, K.; TerAvest, D.; Weebadde, P.; et al. MultispeQ Beta: A Tool for Large-Scale Plant Phenotyping Connected to the Open PhotosynQ Network. R. Soc. Open Sci. 2016, 3, 160592. [CrossRef]

52. Genty, B.; Briantais, J.-M.; Baker, N.R. The Relationship between the Quantum Yield of Photosynthetic Electron Transport and Quenching of Chlorophyll Fluorescence. Biochim. Biophys. Acta (BBA) 1989, 990, 87-92. [CrossRef]

53. Hunt, E.R.; Daughtry, C.S.T. Chlorophyll Meter Calibrations for Chlorophyll Content Using Measured and Simulated Leaf Transmittances. Agron. J. 2014, 106, 931-939. [CrossRef]

54. Tietz, S.; Hall, C.C.; Cruz, J.A.; Kramer, D.M. NPQ(T): A Chlorophyll Fluorescence Parameter for Rapid Estimation and Imaging of Non-Photochemical Quenching of Excitons in Photosystem-II-Associated Antenna Complexes. Plant Cell Environ. 2017, 40, 1243-1255. [CrossRef]

55. Monti, A.; Zatta, A. Root Distribution and Soil Moisture Retrieval in Perennial and Annual Energy Crops in Northern Italy. Agric. Ecosyst. Environ. 2009, 132, 252-259. [CrossRef]

56. Ben Fradj, N.; Rozakis, S.; Borzęcka, M.; Matyka, M. Miscanthus in the European Bio-Economy: A Network Analysis. Ind. Crop. Prod. 2020, 148, 112281. [CrossRef]

57. Wagner, A.; Kaupenjohann, M. Biochar Addition Enhanced Growth of Dactylis Glomerata L. and Immobilized Zn and Cd but Mobilized $\mathrm{Cu}$ and $\mathrm{Pb}$ on a Former Sewage Field Soil. Eur. J. Soil Sci. 2015, 66, 505-515. [CrossRef]

58. Luo, Y.; Lin, Q.; Durenkamp, M.; Dungait, A.; Brookes, P. Soil Priming Effects Following Substrates Addition to Biochar-Treated Soils after 431 Days of Pre-Incubation. Biol. Fertil. Soils 2017, 53, 315-326. [CrossRef]

59. Tikhonenko, D.; Gorin, M.; Laktionov, M.; Kanivec, V.; Medvedev, V.; Baluk, S.; Buligin, S.; Truskaveckii, R.; Kanash, O.; Degtyar'ov, V.; et al. Soil Science: Textbook; Tikhonenko, D., Ed.; Higher Education: Kyiv, Ukraine, 2005; ISBN 966-8081-37-4.

60. Gospodarenko, G. Agrochemistry: Textbook; Agrarian education: Kyiv, Ukraine, 2013; ISBN 978-966-669-317-7.

61. Cadoux, S.; Riche, A.B.; Yates, N.E.; Machet, J.-M. Nutrient Requirements of Miscanthus $\times$ giganteus: Conclusions from a Review of Published Studies. Biomass Bioenergy 2012, 38, 14-22. [CrossRef]

62. Babadzanova, O.; Sukach, Y.; Sukach, P. Phytotoxicity of soils contaminated by diesel. Sci. Bull. Natl. For. Tech. Univ. Ukr. 2017, 27, 92-94.

63. Alkorta, I.; Garbisu, C. Phytoremediation of Organic Contaminants in Soils. Bioresour. Technol. 2001, 79, 273-276. [CrossRef]

64. Shukry, W.; Al-Hawas, G.; Al-Moaik, R.; El-Bendary, M. Effect of Petroleum Crude Oil on Mineral Nutrient Elements and Soil Properties of Jojoba Plant (Simmondsia chinensis). Acta Bot. Hung. 2013, 55, 117-133. [CrossRef]

65. Rahbar, F.G.; Kiarostami, K.; Shirdam, R. Effects of Petroleum Hydrocarbons on Growth, Photosynthetic Pigments and Carbohydrate Levels of Sunflower. J. Food Agric. Environ. 2012, 10, 773-776.

66. Saeed, M.; Ilyas, N. Toxicity of Soil Hydrocarbon Pollution in Field Crops and Its Remediation. In Agronomic Crops: Volume 3: Stress Responses and Tolerance; Hasanuzzaman, M., Ed.; Springer: Singapore, 2020; pp. 603-611. ISBN 9789811500251.

67. Khan, S.; Afzal, M.; Iqbal, S.; Khan, Q.M. Plant-Bacteria Partnerships for the Remediation of Hydrocarbon Contaminated Soils. Chemosphere 2013, 90, 1317-1332. [CrossRef]

68. Merkl, N.; Schultze-Kraft, R.; Infante, C. Phytoremediation in the Tropics-The Effect of Crude Oil on the Growth of Tropical Plants. Bioremediation J. 2004, 8, 177-184. [CrossRef]

69. Kvak, V.; Hanzhenko, O.; Humentyk, M.Y.; Tsvihun, H. Relationship between leaf area, aboveground mass and morphometric indices of Miscanthus. Sci. Pap. Inst. Bioenergy Crop. Sugar Beets 2018, 26, 75-83. [CrossRef]

70. Kvak, V.; Hanzhenko, O.; Zykov, P.; Khivrych, O. Method for determination of leaf area in different sorts of Miscanthus by calculation. Adv. Agrotechnol. 2017, 5, 7. [CrossRef] 
71. Redondo-Gómez, S.; Petenello, M.C.; Feldman, S.R. Growth, Nutrient Status, and Photosynthetic Response to DieselContaminated Soil of a Cordgrass, Spartina argentinensis. Mar. Pollut. Bull. 2014, 79, 34-38. [CrossRef]

72. Baruah, P.; Saikia, R.R.; Baruah, P.P.; Deka, S. Effect of Crude Oil Contamination on the Chlorophyll Content and Morpho-Anatomy of Cyperus brevifolius (Rottb.) Hassk. Environ. Sci. Pollut. Res. 2014, 21, 12530-12538. [CrossRef]

73. Loggini, B.; Scartazza, A.; Brugnoli, E.; Navari-Izzo, F. Antioxidative Defense System, Pigment Composition, and Photosynthetic Efficiency in Two Wheat Cultivars Subjected to Drought. Plant Physiol. 1999, 119, 1091-1100. [CrossRef]

74. Bielczynski, L.W.; Łacki, M.K.; Hoefnagels, I.; Gambin, A.; Croce, R. Leaf and Plant Age Affects Photosynthetic Performance and Photoprotective Capacity. Plant Physiol. 2017, 175, 1634-1648. [CrossRef]

75. Kandel, B.P. Spad Value Varies with Age and Leaf of Maize Plant and Its Relationship with Grain Yield. BMC Res. Notes 2020, 13, 475. [CrossRef]

76. Han, G.; Cui, B.X.; Zhang, X.X.; Li, K.R. The Effects of Petroleum-Contaminated Soil on Photosynthesis of Amorpha fruticosa Seedlings. Int. J. Environ. Sci. Technol. 2016, 13, 2383-2392. [CrossRef]

77. Kramer, D.M.; Johnson, G.; Kiirats, O.; Edwards, G.E. New Fluorescence Parameters for the Determination of QA Redox State and Excitation Energy Fluxes. Photosynth. Res. 2004, 79, 209. [CrossRef]

78. Netto, A.T.; Campostrini, E.; de Oliveira, J.G.; Bressan-Smith, R.E. Photosynthetic Pigments, Nitrogen, Chlorophyll a Fluorescence and SPAD-502 Readings in Coffee Leaves. Sci. Hortic. 2005, 104, 199-209. [CrossRef]

79. Maier, R.M.; Gentry, T.J. Chapter 17-Microorganisms and Organic Pollutants. In Environmental Microbiology, 3rd ed.; Pepper, I.L., Gerba, C.P., Gentry, T.J., Eds.; Academic Press: San Diego, CA, USA, 2015; pp. 377-413. ISBN 978-0-12-394626-3. 